\title{
Developing an aeronautical English training unit based on the ADDIE model in an EFL context
}

Desenvolvendo uma unidade de treinamento de inglês aeronáutico baseada no modelo ADDIE em um contexto EFL

\section{ABSTRACT}

The precision and effectiveness of the communication between air traffic controllers and pilots is quite literally a matter of life or death. Speakers of aeronautical English, the language of communication in the realm of aviation, are required by the ICAO to meet a minimum standard of language performance across the communication skills of listening and speaking, yet miscommunication and misunderstandings across channels persist, potentially resulting in catastrophic collisions and incidents. This English for Specific Purposes (ESP) paper reports on the creation of an aeronautical English training unit guided by principles of the ADDIE (analysis, design, development, implementation, and evaluation) model of instructional design developed to assist Korean army enlisted soldiers and noncommissioned officers who are serving as air traffic controllers in the improvement of integral aeronautical English skills. Designed materials were assessed with the assistance of four subject-matter experts (SMEs) as a pilot test, and results of the evaluation demonstrate the potential for application of the ADDIE model of instructional design for future ESP instructional units.

Keywords: ADDIE model, aeronautical English, English for Specific Purposes (ESP), instructional design

\section{RESUMO}

A precisão e a eficácia da comunicação entre controladores de tráfego aéreo e pilotos é quase literalmente uma questão de vida ou morte. A OACI requer que falantes do inglês aeronáutico, a língua de comunicação no domínio da aviação, atendam a um padrão mínimo de desempenho linguístico nas habilidades comunicativas de compreensão e produção oral, ainda que continuem a ocorrer falhas de comunicação ou mal-entendidos em vários canais, potencialmente resultando em incidentes e colisões catastróficas. Este artigo sobre Inglês para Fins Específicos (ESP) informa sobre a criação de uma unidade de capacitação/treinamento de inglês aeronáutico consoante os princípios do modelo ADDIE (análise, design, desenvolvimento, implementação e avaliação) de design instrucional, desenvolvido para auxiliar suboficiais e soldados alistados do exército coreano que estão servindo como controladores de tráfego aéreo a aperfeiçoarem suas habilidades integrais de inglês aeronáutico. Os materiais elaborados foram avaliados, como um teste-piloto, com a assistência de quatro especialistas

\footnotetext{
${ }^{1}$ The Chinese University of Hong Kong, Shatin, New Territories, Hong Kong SAR, China. Department of Curriculum and Instruction; ORCID: https://orcid.org/0000-0001-9174-9743; moonyoungpark@,cuhk.edu.hk

${ }^{2}$ Iowa State University, Ames, Iowa, U.S.A. Center for Communication Excellence of the Graduate College; ORCID: https://orcid.org/0000-0003-0447-6383; shuffman@iastate.edu
} 
no assunto (SMEs) e os resultados da avaliação demonstram o potencial de aplicação do modelo ADDIE de design instrucional para futuras unidades instrucionais de ESP.

Palavras-Chave: modelo ADDIE, inglês aeronáutico, Inglês para Fins Específicos (ESP), design instrucional

\section{Introduction}

Clear and effective aeronautical English communication between air traffic controllers (henceforth, controllers) and pilots is one of the most critical components of flight safety (CAA, 2006). In aviation communication, although both controllers and pilots communicate on the same radio channel, they often have divergent goals and priorities and operate using different information sources (MIDKIFF; HANSMAN; REYNOLDS, 2004). Therefore, seamless communication is important, as the two parties are required to maintain a continuous mutual understanding of circumstances to share responsibility for efficient and safe air traffic control (ATC). Nevertheless, miscommunications in controller - pilot communications have been reported as a major factor in fatal airplane accidents, airspace incidents, runway incursions and mid-air collisions, and operational failures and pilot deviations (e.g., EUROCONTROL, 2017; PRINZO, 1996). Though numerous factors are involved in the efficient communication between controllers and pilots, including gender, operating environment and procedure, workload, and traffic condition (TIEWTRAKUL; FLETCHER, 2010), language issues in radio transmission have been the most prominent variable involving severe aviation accidents (CUSHING, 1994). An analysis of controller - pilot incidents conducted by EUROCONTROL (2006) also reveals that controller accent and controller speech rate are the most frequent factors contributing to errors (WEVER; ES; VERBEEK, 2006).

In order to enhance the accuracy and effectiveness of controller - pilot communication in aviation, in 1954, the International Civil Aviation Organization (ICAO) recommended that English be globally used for international aeronautical radiotelephony communication (BOSCHEN; JONES, 2004). The ICAO (2004) has further developed a set of language proficiency requirements (LPRs), which consist of six levels of skills in six areas of language use: pronunciation, structure, vocabulary, fluency, comprehension, and interaction. Although such standardization in aeronautical English assessment lays a solid foundation for the improvement of aeronautical English communications, it is not the ICAO, but rather aeronautical English training providers, that carry the responsibility of ensuring effective coverage of all six ICAO skills at an operational level (ICAO, 2009). According to ICAO guidelines, regardless of their first language, controllers, pilots, navigators, and station operators must demonstrate their ability to speak and understand the language used for radiotelephony communications. Despite the 
implementation of the LPRs, however, language and comprehension problems have remained a primary cause of operational airspace incidents (TIEWTRAKUL; FLETCHER, 2010).

Recently, highlighting air traffic controller competency-based training and assessment, ICAO (2016-a) has adopted a five-phase instructional design model called ADDIE: 1) Analysis, 2) Design, 3) Development, 4) Implementation, and 5) Evaluation. The ADDIE model has become one of the most widely adopted instructional design frameworks for creating and assessing potential educational modules and programs (MOLENDA; REIGELUTH; NELSON, 2003). However, there has been no known empirical exploration of the framework in the design and implementation of aeronautical English training programs for air traffic controllers, aside from cabin crew training (e.g., MEISHELLA, 2018; NETO, 2012) and aviation maintenance technician training (e.g., AGLUGUB, 2013). Given the critical importance of improving aviation safety and the paucity of empirical endeavors for instructional design and development practice for controller training, further research is urgently required to demonstrate the feasibility and applicability of the ADDIE model in the development of aeronautical English training modules for air traffic controllers.

In an aim to contribute to the English for Specific Purposes (ESP) area of air traffic control (ATC) English, this paper reports on the detailed instructional design process of an aeronautical English training unit based on the ADDIE model as well as evaluation results of the developed unit by subjectmatter experts (SMEs). This paper will first introduce the ADDIE framework and needs analysis, and then elaborate on the instructional design process and expert military air traffic controllers' evaluative feedback on the training unit.

\section{Literature Review}

\subsection{ADDIE - Instructional design framework}

The ADDIE (analysis, design, development, implementation, and evaluation) model, a standardized and simplified design model for educational systems, serves as an effective and versatile model for building efficient pedagogical instruments to support education and performance (TIAN; SUPPASETSEREE, 2013). Of the more than 100 varied instructional systems design (ISD) models produced, most are based on the generic ADDIE framework (KRUSE, 2011). A summarized breakdown of the actions taken to complete each stage of the ADDIE model is provided below. 
Figure 1. The ADDIE Model of Instructional Design

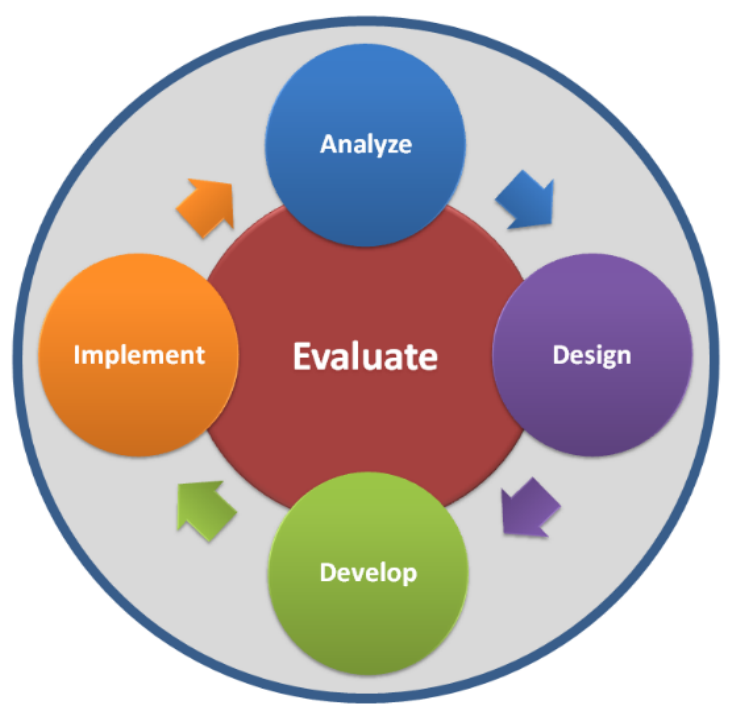

Source: Sexton \& Company (2012)

Analysis Phase. The analysis phase of the ADDIE model is initiated by: identifying the specific problem target learners are experiencing; determining whether or not intervention by instruction would assist in solving this problem; determining the current knowledge base of the learners (e.g., air traffic controllers), characteristics of the learners, preferences for learning environments and learning conditions, the problem and issues surrounding the problem, and learners' and the SMEs' (i.e., four expert military air traffic controllers - one master sergeant and three sergeants first class with 7-16 years ATC experiences) suggestions for how to go about solving the problem (MORRISON; ROSS; KEMP, 2010); discerning whether or not an instructional unit could meet the needs of the clients; and identifying outlined objectives and established factors that could affect successful design implementation.

Design Phase. In the design phase, instructional designers create detailed learning objectives for the unit; generate ideas about content to include in instruction; consider resources to which the learners have access; make decisions on format for delivery, including appearance, usability and interactive features; and understand limitations to expansion of design for larger audiences outside the immediate target learners.

Development Phase. In this phase, the final structure and content of the learning unit are created to correspond to the elements defined in the previous two phases. This phase is essential for the successful implementation of the target learning module. If necessary, the required information and 
communication technology (ICT) tools and resources, as well as specific activities for each step, should be prepared.

Implementation Phase. The implementation phase is where the teacher will disseminate learning materials to target learners and SMEs, who oversee their training; allow a certain time period for unit completion; and gather feedback on the learning contents, incorporated ICT tools, online resources, and assessment criteria from the learners for future improvement ideas.

Evaluation Phase. In this last phase of the ADDIE model, the teacher needs to conduct a final evaluation of the learning module. Depending on the circumstances, either or both types of evaluation a formative evaluation and a summative evaluation - can be adopted during this phase and/or after the phase is complete, respective to evaluation type. The teacher can also define and redefine an instructional unit's objectives and activities, make decisions based on new information or newly identified parameters, make modifications to the unit or plans, and collect summative feedback by creating surveys for students to evaluate the unit.

\subsection{Key development components supplementing ADDIE model}

The generic ADDIE framework offers valuable insight into procedures for the development and implementation of an instructional program. However, the creation and practice of an instructional unit still requires a great deal of groundwork and decision making and should be backed by sound rationale derived from the learners' indicated needs.

Conducting a needs analysis. Understanding the target context and learners is an important step to take before implementing any new teaching approaches or methods (BROWN, 1995). To best serve the analysis phase, the initial phase of the ADDIE model comprises conducting a needs analysis. Along these lines, a comprehensive definition of needs analysis - that takes contextual factors (e.g., target content, delivery mode, and evaluation methods) into account—is proposed by Brown (1995, p. 36); "the systematic collection and analysis of all subjective and objective information is necessary to define and validate defensible curriculum purposes that satisfy the language learning requirements of students within the context of particular institutions that influence the learning and teaching situation." Needs analysis is used not only for the development of language programs, but also for program evaluation and curriculum improvement (ALDERSON; SCOTT, 1992). However, despite the significant role of the needs analysis in the successful establishment and evolution of a language program, few studies (e.g., SILVA; TOSQUI-LUCKS, 2020; KARIMI; SANAVI, 2014; SHIN; KIM, 2005) have been conducted on the needs analysis in aeronautical English training contexts. 
Selecting content. As highlighted in Morrison, Ross, and Kemp (2010), it is the perspective of target learners, not the content itself, which should be at the center of the instructional design process. Selecting content for an instructional unit is a major decision that can be based on the results of the learners' needs analysis as well as the SMEs' advice. Selecting the content, thus, necessitates a return to the initial assessment of the target learners about their desire to improve their knowledge and skills. Providing an opportunity for learners to practice their knowledge and skills in simulated environments that mirror the actual communicative contexts of their jobs can provide a bridge to what Morrison et al. (2010) term transfer contexts, outside contexts in which learners can observe their new skills or knowledge being applied.

Deciding on delivery mode. Choosing the mode of delivery of the instructional unit also marks a key point in the Design and Development stages of the ADDIE Model. The physical distance of the learners (e.g., recent online teaching and learning during the COVID-19 pandemic) plays a major role in choosing a mode of delivery. Instructional designers have to select a mode of delivering the instructional materials that would allow learners not only speedy access to materials, but also flexibility of access in when and how they would receive and interact with the materials. Parrish $(2009$, p. 517) argues that "the success of scenarios in instruction may depend greatly on careful manipulation of context.... to create the alternative world and to encourage immersion and genuine participation".

Incorporating motivational strategies. In the Design and Development phases of the ADDIE model, instructional designers should make decisions about the presentation of the unit, taking into consideration Keller's (1987) ACRS Motivation Model, which focused on the four fundamental components - attention, confidence, relevance, and satisfaction - that should be present in instruction to promote and sustain learner motivation. Keller's ARCS Model asks the important questions "What will you do to make the instruction valuable and stimulating for your students?" and "How will you help your students succeed and feel that they were responsible for their success?" (p. 2). One way of ensuring success for target learners is instructional designers' attempts to connect the learners' new knowledge with previous knowledge. The learning unit could start with familiar topics and content, and slowly introduce new knowledge and skills, so as not to overwhelm the learners initially, but still propel their learning in a scaffolded way. More importantly, instructional designers aim to obtain and sustain the learners' attention to the unit and materials by sparking curiosity in the learners (BERLYNE, 1965).

\section{Development of an aeronautical English Training Unit - Aeronautical English 101 for Controllers}




\subsection{Needs and content analysis findings}

To identify target learners' needs and characteristics of the target context in this study, a needs analysis survey was conducted with seven military air traffic controllers in Korean army aviation units. The survey participants can be categorized into two groups: (1) enlisted soldiers $(n=1$, rank $=$ sergeant) and (2) noncommissioned officers $(\mathrm{NCO})(\mathrm{n}=6$, rank $=1$ staff sergeant, 4 sergeant first class, and 1 master sergeant). One enlisted soldier ( 24 years old) was a male who had been drafted to fulfill the country's mandatory two-year military service. The noncommissioned officers' ages ranged from 25 to 36 and all had graduated from the Army NCO Academy after completion of high school or a community college. All of the NCO participants were also male. An online survey questionnaire (see Appendix), including both Likert-scale closed-ended question items and qualitative open-ended items, was administered to examine controllers' specific problems and needs in aeronautical English and to determine to what extent and in what ways target learners need aeronautical English instruction and how the learners visualize the objectives for and means of improving their aeronautical English.

The needs analysis results confirm there is, in fact, a need for the target learners to improve their aeronautical English skills, particularly in the language learning skill sets of listening and speaking. The survey responses also show the learners are highly motivated to improve their aeronautical English proficiency, as they believe enhanced aeronautical English skills and more effective use of ATC phraseology will allow them to be more successful at their jobs as air traffic controllers. The survey respondents also want to be able to better communicate with native English speaking U.S. Army pilots stationed in Korea, especially in specified situations such as providing flight information, understanding and using English idioms and vocabulary not in textbooks, and incorporating current knowledge of ATC vocabulary into fluent speech production.

Needs analysis findings also reveal that the target learners have experienced little or no difficulty understanding Korean pilots' aeronautical English speech, but they have experienced difficulty or extreme difficulty in deciphering radiotelephony from the U.S. army pilots, in particular with challenges concerning comprehending native English speaking pilots' English pronunciation, keeping up with those pilots' speed of speech, and understanding non-standard aviation phraseology. In open-ended responses, the survey respondents indicated they wish to improve understanding of English idioms and vocabulary not available in the ATC textbooks, use their current knowledge of aeronautical English vocabulary and grammar to produce fluent speech in aeronautical English communication, and improve their English accent or pronunciation to make their spoken language more intelligible to the U.S. pilots. 
Based on the results of the content analysis of the Army Aeronautical English Manuals, the researchers created an outline of the objectives of the instruction and a subsequent description of tasks to be included in the instructional unit. Taking into account that the mastery of aeronautical English involves complex interactions with the target language in a number of situations, only some of which can be simulated in a testing environment, the researchers focused the unit objectives not on the mastery of aeronautical English as a whole, but on the improvement of listening and speaking skills within a few specific situations. The objectives of the unit are as follows:

[Listening skills]

Learners will be able to:

- listen to authentic passages in realistic ATC contexts

- listen to native English speakers' pronunciation

- listen to idiomatic expressions and non-standard language phrases not taught in ATC textbooks through more interaction, including the capability of immediately responding to listening passages

[Speaking skills]

Learners will be able to:

- produce authentic spoken communication in realistic ATC contexts

- practice pronunciation of aeronautical English phrases

- practice using new idiomatic expressions and non-standard language phrases not taught in ATC textbooks through more dynamic interaction with listening passages by enabling immediate learner-spoken response

Findings from the online needs analysis survey indicate that the majority of the participants prefer computer-mediated instruction to enhance their English communication skills. Moreover, given the contextual restriction, the physical distance between the instructional designers (i.e., the researchers) in the U.S. and the target learners in Korea, the use of online ICT tools and platforms as a delivery mode represented the most practical format for the researchers.

Regarding the motivational strategies, the researchers consider the four components of the ARCS model in the design of the aeronautical English learning unit. In order to capture and maintain target learners' attention to the instructional components, the researchers have secured a Moodle 
website, an open source learning management system (LMS), on which to store and present the instructional unit. Links to live ATC communication on the Moodle site help spark learners' curiosity to what is currently being communicated in aeronautical English by native speakers. Also, because the unit activities will be integrated, combining both listening and speaking tasks in reviews of newly learned vocabulary and expressions, learners' engagement with the materials will be enhanced by their need to respond in a quick-paced, authentic-like environment.

To resolve any potential target learner anxiety and help build learners' confidence, researchers accounted for the quick pace of speech of the American pilots by providing written scripts of the speech for select activities. Supplemental materials, including the use of visual cues (in images or written text in English or Korean), are provided to enhance learners' understanding of the new vocabulary and native English expressions. The content of the instructional unit is also displayed in a format that allows the learners to access the information easily and in a clear, logical way; this involves a unit progression that includes scaffolding upon previously learned knowledge of aeronautical English.

Based on the findings from the needs analysis and content analysis, the researchers aimed to place all unit materials within the context of aeronautical English that target learners would actually encounter in their daily jobs in communication with American and Korean military pilots. The subject matter is relevant in that all situations (e.g., emergency landings, request for take-off, providing weather information) simulated the environment of military air traffic controllers' target language use (TLU) (BACHMAN; PALMER, 1996) situations. The unit, thus, demonstrates relevance to the target learners by facilitating the utility of the learned knowledge within the scope of their real world.

The researchers also used satisfaction-generating strategies that allow the learners to come away from the instructional unit with a sense that relevant knowledge has been acquired. In including only information pertinent to the learners' improvement of their listening and speaking skills in aeronautical English, "students understand how the concepts and skills are related to their goals" (KELLER, 1987, p. 3) for being successful at their air traffic control jobs. Background knowledge of aeronautical English is built up by requiring learners to recognize and review language content (e.g., new aeronautical English terminology) before asking the learners to build upon the knowledge (e.g., in initiating a response sequence with a pilot) requiring use of those specific terms.

\subsection{Major components of the Aeronautical English 101 for Controllers}

Major components of the aeronautical English training instruction, consistent with our instructional design model, the ADDIE model, comprise aeronautical English listening and speaking, dictation, and feedback. All sequences of the instructional design are cyclical and are assessed by 
findings from ongoing evaluation from the needs analysis survey and document analysis of the Army Aeronautical English Manuals and aeronautical English research articles (e.g., ALDERSON, 2009; MOERE et al., 2009). The objectives of the instructional unit are to enhance army air traffic controllers' communication ability, especially focusing on aeronautical English listening and speaking skills based on the knowledge of aeronautical English phraseology. The target learners of this instruction include Korean army enlisted soldiers and noncommissioned officers who are serving as air traffic controllers.

The context of instruction is an extracurricular aeronautical English training center where the addressed target population voluntarily gather together and practice aeronautical English during their free time on the military base. Currently, this group of participants does not have any specific instructional guidelines or formal instructor, but instead use an English pop song book that is designed for English learning. The voluntary learners are expected to practice aeronautical English using the provided materials during their leisure time as a group or individually, depending on the contextual restrictions of the military base. A prerequisite needed for participation in the current instructional unit is a working background knowledge in aeronautical English radio phraseology and previous work experience as an air traffic controller.

To provide the learners with meaningful feedback online, the researchers have used Moodle as a medium for posting correct answers and comments from the researchers and the performance evaluators at the military base. As the learners will engage in aeronautical English dictation online to improve their listening skills and in speaking activities to practice English pronunciation, the researchers must prepare various forms of computer files containing full scripts, and audio and video files to provide mini lectures and corrective feedback on frequently occurring pronunciation errors. Aeronautical English assessment can be implemented through each activity, as the learners need to produce written or spoken language as the final products of the activities. Likewise, the learners will be engaged in a self-assessment activity via Moodle through embedded online quizzes.

\subsection{Topics to cover:}

\subsubsection{Pronunciation practice (recognition, production)}

For the target learners' aeronautical English pronunciation practice, they will first listen to the following aviation terminologies and expressions audio-recorded by native English speakers. To obtain a visualized demonstration of the spoken aeronautical English terms, they can play the recorded audio files with the computer-based audio recorder Audacity (https://www.audacityteam.org/), so that they can view native English speakers' waveforms (in pitch, intonation, and word stress) and compare them with their own version of the audio files. 
Table 1. Aeronautical English radio-phraseology (vocabulary and expressions) (ICAO, 2016-b)

\begin{tabular}{|c|c|}
\hline Acknowledge & Leaving control zone \\
\hline Affirm & Line up and wait \\
\hline Air Defense Identification Zone & Passing control zone boundary \\
\hline Air Evacuation Flight & Position report \\
\hline Air Traffic Control & Radar Approach Control \\
\hline Air Traffic Control Center & Ready for departure \\
\hline Approved & Report ready for departure \\
\hline Attention All Aircraft & Request \\
\hline Change ETA & Request approved \\
\hline Cleared for take off & Request frequency change \\
\hline Cleared to land & Request air-taxiing \\
\hline Continue Approach & Request to cross Runway 20 \\
\hline Correction & Request transition South to North \\
\hline Disregard & Say again \\
\hline Flight Coordination Center & Speak slower \\
\hline Flight Operations Center & Stand by \\
\hline Flight Plan & Take off immediately \\
\hline Frequency & Taxi approved \\
\hline Holding point & Taxi without delay \\
\hline How do you read? & Touch and Go \\
\hline Korea Air Defense Identification Zone & Traffic in sight \\
\hline Maintain & Use caution \\
\hline Make circle to right & Vacate runway \\
\hline Make short approach & Weak and unreadable \\
\hline Negative & Wilco \\
\hline
\end{tabular}

\subsubsection{Rate of speech (recognition/comprehension, production)}

Learners can practice listening to the provided aeronautical English speech by playing the MP3 files at faster or slower speeds using Audacity, an audio recorder/player program that allows for varying speed outputs. Additionally, the learners will be provided with Google Speech to Text or Microsoft Speech Recognition application software for their speech practice. 


\subsubsection{New vocabulary acquisition and practice (individual words)}

New vocabulary items were first verified against the Army Aviation English Manuals and are summarized above in Table 1. Results from the needs analysis suggest that listening and speaking skills are of great importance yet the most challenging among the English language skill sets in aeronautical English communication in learners' authentic ATC jobs. Thus, the instructional components are derived directly from both SMEs and the learner-cited needs for improving aeronautical English.

\subsubsection{Practice activities and sequencing}

The specific activities comprising the "Aeronautical English 101 for Controllers" unit were developed based on the needs and preferences for aeronautical English instruction that learners' indicated on the needs analysis survey. Activities aim to target phraseology the survey respondents specified as being problematic, such as unknown ATC vocabulary, and effectively responding to and comprehending native English speaking pilots. For each activity, vocabulary and English phrases (see Table 1) are grouped according to relevance of the topic area. (For example, several vocabulary items related to take off instructions will appear in the same grouping.) The content is organized according to complexity, with single words and phrases separated from more lengthy, complex phraseology. Learners will then complete the instructional unit following a recognition-, comprehension-, application-oriented sequence of steps. A detailed summary of the activities to be included in the unit is shown in Table 2 .

Table 2. Summary of "Aeronautical English 101 for Controllers" activities

\begin{tabular}{|l|l|l|l|}
\hline \multicolumn{1}{|c|}{ Activity } & \multicolumn{1}{|c|}{ Skill Focus } & \multicolumn{1}{|c|}{ Provided Feedback } & \multicolumn{1}{c|}{$\begin{array}{c}\text { Required } \\
\text { Materials }\end{array}$} \\
\hline $\begin{array}{l}\text { (1) Listen to and provide } \\
\text { dictation for short audio } \\
\text { passage that highlights } \\
\text { new, simple } \\
\text { phraseology, then } \\
\text { provide meaning of new } \\
\text { vocabulary in Korean } \\
\text { recognition and } \\
\text { comprehension }\end{array}$ & $\begin{array}{l}\text { General feedback on correct } \\
\text { dictation and Korean meaning } \\
\text { provided by instructor on } \\
\text { Moodle }\end{array}$ & $\begin{array}{l}\text { Mp3 recordings of } \\
\text { passages spoken by } \\
\text { native English } \\
\text { speakers; } \\
\text { earphones; text } \\
\text { editor for } \\
\text { notetaking }\end{array}$ \\
\hline $\begin{array}{l}\text { (2) Practice saying short } \\
\text { passages of new } \\
\text { phraseology }\end{array}$ & $\begin{array}{l}\text { Speaking: } \\
\text { application }\end{array}$ & $\begin{array}{l}\text { Specific feedback provided by } \\
\text { instructor on learners' } \\
\text { pronunciation; Specific } \\
\text { feedback provided by } \\
\text { computer software } \\
\text { highlighting distinctions in } \\
\text { learners' and native-speakers' } \\
\text { pronunciation }\end{array}$ & $\begin{array}{l}\text { Microsoft } \\
\text { automated speech } \\
\text { recognition (ASR) } \\
\text { tool; Audacity } \\
\text { audio recording } \\
\text { software; } \\
\text { microphone }\end{array}$ \\
\hline
\end{tabular}




\begin{tabular}{|c|c|c|c|}
\hline $\begin{array}{l}\text { (3) Practice pronouncing } \\
\text { report of flight plan } \\
\text { based on provided flight } \\
\text { information (i.e., arrival } \\
\text { time, flight number, etc.) }\end{array}$ & $\begin{array}{l}\text { Speaking: } \\
\text { recognition and } \\
\text { application }\end{array}$ & $\begin{array}{l}\text { Specific feedback provided by } \\
\text { instructor on learners' } \\
\text { pronunciation; Specific } \\
\text { feedback provided by } \\
\text { computer software } \\
\text { highlighting distinctions in } \\
\text { learners' and native-speakers' } \\
\text { pronunciation }\end{array}$ & $\begin{array}{l}\text { Microsoft's ASR } \\
\text { tool; Audacity } \\
\text { software; } \\
\text { microphone }\end{array}$ \\
\hline $\begin{array}{l}\text { (4) Listen to and provide } \\
\text { dictation for longer } \\
\text { passage or dialogue } \\
\text { incorporating complex } \\
\text { ATC phraseology, and } \\
\text { summarize meaning of } \\
\text { dialogues in Korean }\end{array}$ & $\begin{array}{l}\text { Listening: } \\
\text { recognition and } \\
\text { comprehension }\end{array}$ & $\begin{array}{l}\text { General feedback on correct } \\
\text { dictation and Korean meaning } \\
\text { provided by instructor on } \\
\text { Moodle }\end{array}$ & $\begin{array}{l}\text { Mp3 recordings of } \\
\text { passages spoken by } \\
\text { native English } \\
\text { speakers; text editor } \\
\text { for notetaking; } \\
\text { earphones }\end{array}$ \\
\hline $\begin{array}{l}\text { (5) Respond orally to } \\
\text { longer listening passage } \\
\text { incorporating complex } \\
\text { ATC phraseology }\end{array}$ & $\begin{array}{l}\text { Speaking: } \\
\text { recognition, } \\
\text { comprehension, } \\
\text { and application }\end{array}$ & $\begin{array}{l}\text { Specific feedback provided by } \\
\text { instructor on learners' } \\
\text { pronunciation and } \\
\text { appropriateness of oral } \\
\text { response; Specific feedback } \\
\text { provided by computer software } \\
\text { highlighting distinctions in } \\
\text { learners' and native-speakers' } \\
\text { pronunciation }\end{array}$ & $\begin{array}{l}\text { Microsoft's ASR } \\
\text { tool; Audacity } \\
\text { software; } \\
\text { earphones; } \\
\text { microphone }\end{array}$ \\
\hline $\begin{array}{l}\text { (6) Compose and } \\
\text { respond orally to given } \\
\text { situation using new } \\
\text { phraseology } \\
\text { appropriately in context }\end{array}$ & $\begin{array}{l}\text { Listening and } \\
\text { speaking: } \\
\text { recognition, } \\
\text { comprehension, } \\
\text { and application }\end{array}$ & $\begin{array}{l}\text { Specific feedback provided by } \\
\text { instructor on learners' } \\
\text { pronunciation and } \\
\text { appropriateness of oral } \\
\text { response; Specific feedback } \\
\text { provided by computer software } \\
\text { highlighting distinctions in } \\
\text { learners' and native-speakers' } \\
\text { pronunciation }\end{array}$ & $\begin{array}{l}\text { Mp3 recordings of } \\
\text { passages spoken by } \\
\text { native English } \\
\text { speakers; text editor } \\
\text { for notetaking; } \\
\text { Microsoft's ASR } \\
\text { tool; Audacity } \\
\text { software; } \\
\text { earphones; } \\
\text { microphone }\end{array}$ \\
\hline
\end{tabular}

The sequencing of the activities enables learners to progress from less to more complicated tasks, from basic recognition and comprehension to application of the new phraseology. The activities will likewise scaffold learners' understanding of previously learned content by starting with simple, singular words and phrases then progress to more complex phrases and extended listening and speaking passages. This will allow the air traffic controllers to begin incorporating their new knowledge of ATC phraseology into their existing aeronautical English knowledge and slowly work towards improving 
language skills, such as recognizing terms in faster speeds of speech and native speakers' pronunciation and improving their own pronunciation.

The materials required in the unit are selected based on learners' responses to the needs analysis questions about preferred instructional resources. Respondents indicated they enjoyed instructional materials, such as MP3s, so both shorter and longer audio files of native English dialogue and speech are provided in this unit. The selected materials also hold the potential to be accessed by learners who may not have the financial means to pay for commercial language learning products. For example, both audio recording software tools are available for students to download. The Microsoft automated speech recognition (ASR) tool accompanies every Microsoft package, all of which the learners own. Also, Audacity is a free audio recording software downloadable from the internet. The chosen tools are also considered sophisticated technological applications that enable enhanced learner recognition of speech patterns. Microsoft ASR has the functionality of learning users' speech over time, and Audacity provides visual displays of users' tone, pitch, and volume so learners can view a physical representation of and identify linguistic problems with their word stress and speech rhythm. Microphones and earphones will be the only other necessary resources to which learners will need access. Joining listening and speaking tasks will allow the target audience a chance to employ their learned knowledge of ATC phraseology and pronunciation and speech comprehension skills in a dynamic, integrated environment.

\section{Evaluation of the Aeronautical English 101 for Controllers}

\subsection{Methods to evaluate the instruction}

The researchers adopted an end-of-unit evaluation for four SMEs to evaluate the instruction of the unit as a pilot test. For this reason, no formative evaluation was adopted in this study. Those who evaluated the unit were four expert military air traffic controllers, all males and NCOs (one master sergeant and three sergeants first class) with an average number of years of military ATC experience at nine years (ranging from six years to 16 years). To develop the evaluation instrument, a Google docs survey form was adopted and the online link was posted on the Moodle page so that the SMEs could access the evaluation link after exploring the developed activities. The unit evaluation includes both close multiple-choice and open-ended questions that set out to establish what knowledge was gained in the instructional unit as compared to what baseline knowledge the air traffic controllers had prior to instruction and centered on components of the delivery, relevance, and appropriateness of content, quality of instructional materials, and usability of the aeronautical English training unit on the Moodle. 
As recommended in Morrison et. al. (2010), the summative evaluation was designed to elicit responses from learners regarding perceived effectiveness of the unit, attitudes and reactions to the unit, and projected long-term benefits of, as well as recommendations for improvement for, the instructional unit. Specifically, the following questions in Table 3 were composed to elicit learner feedback targeting the categories referring to Morrison et al. (2010).

Table 3. Criteria and questions for evaluating an aeronautical English training unit

\begin{tabular}{|c|c|}
\hline $\begin{array}{l}\text { Criteria for Evaluating } \\
\text { Instructional Programs } \\
\text { (Morrison et al., 2010) }\end{array}$ & $\begin{array}{c}\text { "Aeronautical English } 101 \text { for Controllers" Unit Evaluation } \\
\text { Questions Addressing Evaluative Criterion }\end{array}$ \\
\hline Content accuracy & $\begin{array}{l}\text { - Please explain what you expected from this instructional unit. } \\
\text { to someone else who wanted to improve her/his aeronautical } \\
\text { English listening or speaking skills? }\end{array}$ \\
\hline $\begin{array}{l}\text { Appropriateness of } \\
\text { objectives }\end{array}$ & $\begin{array}{l}\text { - Did this instructional unit target skills you were concerned } \\
\text { about improving? } \\
\text { - How likely would you be to use this instructional unit again? } \\
\text { How likely would you be to recommend this instructional unit } \\
\text { to someone else who wanted to improve her/his aeronautical } \\
\text { English listening or speaking skills? }\end{array}$ \\
\hline Instructional quality & $\begin{array}{l}\text { - Did you complete all of the listening/speaking activities? } \\
\text { Please explain why you did or did not complete all the } \\
\text { listening/speaking activities. } \\
\text { - To what extent do you think the following activities were } \\
\text { effective at improving your listening/speaking skills? } \\
\text { - To what extent do you believe your listening/speaking skills in } \\
\text { the following areas have improved? } \\
\text { - How likely would you be to use this instructional unit again? } \\
\text { - How likely would you be to recommend this instructional unit } \\
\text { to someone else who wanted to improve her/his aeronautical } \\
\text { English listening or speaking skills? }\end{array}$ \\
\hline Visual design & $\begin{array}{l}\text { - How appealing did you find the visual design of this } \\
\text { instructional unit? } \\
\text { - How effective was the Moodle site in which the instructional } \\
\text { unit was delivered? }\end{array}$ \\
\hline Usability & - How user friendly did you find this instructional unit? \\
\hline
\end{tabular}

\subsection{Findings from user evaluation}

The following is a summary of the quantitative and qualitative responses to the unit evaluation, the four expert military air traffic controllers' general and specific impressions of the "Aeronautical 
English 101 for Controllers" instructional unit, according to the four categories (i.e., content accuracy, instructional quality, visual design, and usability) Morrison et al. (2010) offer for evaluating effective instruction.

Table 4. Summary of the evaluation survey responses

Evaluation inquiry:

\begin{tabular}{|c|c|c|c|c|c|}
\hline 1 & $\begin{array}{l}\text { [Content accuracy] } \\
\text { How likely would you be to recommend this instructional unit to } \\
\text { someone else who wanted to improve her/his ATC English listening } \\
\text { or speaking skills? }\end{array}$ & $\begin{array}{c}0 \\
(0 \%)\end{array}$ & $\begin{array}{c}2 \\
(50 \%)\end{array}$ & $\begin{array}{c}1 \\
(25 \%)\end{array}$ & $\begin{array}{c}1 \\
(25 \%)\end{array}$ \\
\hline 2 & $\begin{array}{l}\text { [Appropriateness of objectives] } \\
\text { Did this instructional unit target skills you were concerned about } \\
\text { improving? }\end{array}$ & \multicolumn{2}{|c|}{$\begin{array}{c}\text { No } \\
1 \\
(25 \%)\end{array}$} & \multicolumn{2}{|c|}{$\begin{array}{c}\text { Yes } \\
3 \\
(75 \%)\end{array}$} \\
\hline 3 & How likely would you be to use this instructional unit again? & $\begin{array}{c}0 \\
(0 \%) \\
\end{array}$ & $\begin{array}{c}1 \\
(25 \%)\end{array}$ & $\begin{array}{c}2 \\
(50 \%) \\
\end{array}$ & $\begin{array}{c}1 \\
(25 \%) \\
(25 \%\end{array}$ \\
\hline 4 & $\begin{array}{l}\text { [Instructional quality] } \\
\text { To what extent do you believe your listening skills in the following } \\
\text { areas have improved: Listening to and understanding native English } \\
\text { speakers' speed of speech }\end{array}$ & $\begin{array}{c}0 \\
(0 \%)\end{array}$ & $\begin{array}{c}1 \\
(25 \%)\end{array}$ & $\begin{array}{c}2 \\
(25 \%)\end{array}$ & $\begin{array}{c}1 \\
(25 \%)\end{array}$ \\
\hline 5 & $\begin{array}{l}\text { To what extent do you believe your listening skills in the following } \\
\text { areas have improved: Listening to and understanding native English } \\
\text { speakers' ATC phraseology }\end{array}$ & $\begin{array}{c}0 \\
(0 \%)\end{array}$ & $\begin{array}{c}1 \\
(25 \%)\end{array}$ & $\begin{array}{c}2 \\
(50 \%)\end{array}$ & $\begin{array}{c}1 \\
(25 \%)\end{array}$ \\
\hline 6 & $\begin{array}{l}\text { To what extent do you believe your listening skills in the following } \\
\text { areas have improved: Listening to and understanding native English } \\
\text { speakers' accents }\end{array}$ & $\begin{array}{c}0 \\
(0 \%)\end{array}$ & $\begin{array}{c}0 \\
(0 \%)\end{array}$ & $\begin{array}{c}4 \\
(100 \%)\end{array}$ & $\begin{array}{c}0 \\
(0 \%)\end{array}$ \\
\hline 7 & $\begin{array}{l}\text { To what extent do you believe your speaking skills in the following } \\
\text { areas have improved: Pronunciation of ATC English }\end{array}$ & $\begin{array}{c}1 \\
(25 \%)\end{array}$ & $\begin{array}{c}1 \\
(25 \%)\end{array}$ & $\begin{array}{c}2 \\
(50 \%)\end{array}$ & $\begin{array}{c}0 \\
(0 \%)\end{array}$ \\
\hline 8 & $\begin{array}{l}\text { To what extent do you believe your speaking skills in the following } \\
\text { areas have improved: Ability to say new ATC English }\end{array}$ & $\begin{array}{c}0 \\
(0 \%) \\
\end{array}$ & $\begin{array}{c}2 \\
(50 \%) \\
\end{array}$ & $\begin{array}{c}1 \\
(25 \%) \\
\end{array}$ & $\begin{array}{c}1 \\
(25 \%) \\
\end{array}$ \\
\hline 9 & $\begin{array}{l}\text { [Visual Design] } \\
\text { How appealing did you find the visual design of this instructional } \\
\text { unit? }\end{array}$ & $\begin{array}{c}0 \\
(0 \%)\end{array}$ & $\begin{array}{c}2 \\
(50 \%)\end{array}$ & $\begin{array}{c}1 \\
(25 \%)\end{array}$ & $\begin{array}{c}1 \\
(25 \%)\end{array}$ \\
\hline 10 & $\begin{array}{l}\text { [Usability] } \\
\text { How effective was the Moodle site in which the instructional unit was } \\
\text { delivered? }\end{array}$ & $\begin{array}{c}0 \\
(0 \%)\end{array}$ & $\begin{array}{c}1 \\
(25 \%)\end{array}$ & $\begin{array}{c}1 \\
(25 \%)\end{array}$ & $\begin{array}{c}2 \\
(50 \%)\end{array}$ \\
\hline
\end{tabular}

\subsubsection{Content accuracy}

A major aim of the instructional unit was to ensure the content could be matched to the actual needs learners had indicated in the needs analysis to establish "a direct relationship between instructional objectives and items" (MORRISON et al., 2004, p. 271). Listed activities in Table 2 were designed in reference to specific needs and problems identified in the needs analysis. All of the four 
expert controllers agreed that the aeronautical English phraseology and aeronautical English listening and speaking activities are authentic and the learning content is expected to help novice air traffic controllers to enhance their English listening and speaking skills. One concern the domain experts pointed out is that it might be challenging for novice air traffic controllers to provide reliable and indepth content accuracy feedback, as their level of ATC knowledge and aeronautical English communication proficiency may not yet be sufficient. Therefore, it would be necessary to include SMEs, as well as the target learners, in the evaluation process to obtain more accurate content evaluation.

\subsubsection{Appropriateness of objectives}

It is important for the instructional designers to establish a training unit appropriately outlined with training objectives for the target learners. When the SMEs were asked about the appropriateness of training objectives, $75 \%$ of the expert controllers agreed that the unit targeted skills they were concerned about improving, as seen in the results summary in Table 4. Also, all of the respondents agreed that they would be likely to use these instructional units again. These results, along with results of a question described in the previous section, indicate that the SMEs found the instructional objectives appropriate for those who want to improve their ATC phraseology and listening and speaking skills in aeronautical English communication. The SMEs were able to see the genuineness of the materials, noting that "I was able to sense the authentic situation." The researchers considered it a success that the expert controllers' perceived the unit as meeting their expectations in terms of instructional objectives.

\subsubsection{Instructional quality}

One area in which these expert controllers were able to better critique the unit was its instructional quality. In terms of what activities were more or less effective at helping novice controllers to improve their listening and speaking skills in aeronautical English communication, the expert controllers responded that speaking activities requiring them to incorporate new phraseology were effective, as were listening activities that involved listening to authentic speech samples from native English speaking pilots. The unit materials, such as the Audacity recorder/playback tool in audio passages, Microsoft's automated speech recognition tool, and the text editor for note-taking, were also seen as "effective" or "highly effective" at helping to improve the novice controllers' listening and speaking skills. Less effective were activities such as those requiring students to respond immediately to a passage or listening to shorter audio passages. 
In terms of how students' listening and speaking skills actually improved after completing the instructional unit, the results of the unit evaluation indicate that novice controllers are expected to increase both listening and speaking skills through the unit. As can be seen in Table 4, three out of the four participants self-reported some to a great deal of improvement in listening to native speakers' speed of speech and phraseology in aeronautical English. Also, all four noted some improvement in their ability to listen to and understand native English speakers' accents after the instructional unit. Speaking skills, on the other hand, were less improved than respondents' listening skills. One of four participants noted there was no improvement whatsoever in their pronunciation of aeronautical English. Likewise, the participants' ability to speak new aeronautical English phraseology was also less improved, with two of the four respondents remarking they saw very little improvement. Unlike listening practice, it seems integral to adopt human interlocutors or human instructors to facilitate more interactive and engaging speaking practice.

\subsubsection{Visual design}

The visual design of the aeronautical English training unit was important for the researchers to determine, as the learning environment carries the ability to reduce or increase potential anxiety in the audience (Keller, 1987). It is highly critical for the environment not only to be attractive, but also to foster a logical progression through the activities, with each activity building on the next to scaffold student learning of aeronautical English phraseology. Unfortunately, one of the four expert controllers noted the training unit to be visually unappealing, which shows clear room for improvement for the unit. It would be helpful to discern specific design elements that could be improved to better address learner preferences for learning environment design.

\subsubsection{Usability}

Another component of evaluating the effectiveness of an instructional unit is discerning how usable, or easy to use, the unit is. This aspect is particularly important for this study, because in an online learning environment, and with target learners with a limited capacity to communicate in English, there may be the tendency for the learners to get lost as they take part in the online instruction. The visual cues and instructions for the unit need to be clear and understandable so the learners can follow without becoming confused about how to proceed or how to complete the activities. One issue that arose multiple times in the unit evaluation was the need for clearer instructions. One SME noted that "it is confusing whether incomplete parts of the given dialogue needs to be filled out," and another remarked that "It might be helpful for learners to know what is required to be done if you (i.e., instructional designers) provide more detailed information regarding the task such as a required length of each 
response." Instructions need to be clear enough so that learners can follow them easily and independently to complete the associated activities.

Expert controllers, however, mostly found the Moodle platform an effective learning environment. Two expert controllers noted it was a very effective delivery system and only one pointed to it being somewhat effective. In terms of unit completion, it took some expert controllers approximately one hour to complete the unit, while others completed it in non-consecutive sessions over the course of several days. This, of course, may present an inaccurate time description from these respondents, as many had indicated they did not complete all the tasks and were simply aiming to evaluate the instruction for the researchers.

\section{Recommended Revisions to Instruction}

This study represents a modest, but empirically sound and learner-oriented attempt to respond to the needs of a population often disregarded in the creation of ESP materials for a high-stakes communication context. Researchers were able to capitalize on valuable and rarely accessed feedback from acting Korean military personnel to craft an instructional unit that was built directly from the comprehensive input of potential target users, the learners of aeronautical English. Use of the ADDIE model for instructional design enabled a systematic and theory-based development of the learning materials and environment, from needs analysis to unit evaluation stages.

Taking into consideration the results of the unit evaluation and other potential drawbacks of which the researchers were conscious during the unit development, some recommendations should be outlined for revision to the instruction. Firstly, it is evident the aeronautical English training unit must incorporate much clearer instructions. The researchers could make it obvious at the onset of the Moodle unit, in the starting "topic" block, what is to be completed and, perhaps, even supply an approximated time period that students may need to set aside to complete each activity in "Aeronautical English 101 for Controllers." Also, the researchers could better articulate instructions for individual activities, specifying chronological ordering for exactly how the student should proceed, which MP3 files to access, and how to record speech and upload these recordings, for example. Enhancement of the visual design of the unit could also be considered. This could involve playing on recognizable and familiar images (such as the logo of the Korean Army Aviation Force or other such familiar images) and incorporating known fonts, backgrounds, and environments in the Moodle unit webpage and on the activity documents. This will help frame the subject matter as a "tangible activity" related to learners' operating environments (PARRISH, 2009, p. 516). 
However, some limitations in this study are worth noting. Firstly, the research findings were based solely on the insights from domain experts who work daily in TLU situations and are similarly familiar with not only the skills, but also the level of competency target learners need to hold in the accomplishment of tasks. Potential follow-up research may include a full-scale implementation of the training unit to investigate the actual learning outcomes of the target learners. Secondly, the development of this training unit lacked truly authentic resources. Because of the confidentiality associated with accessing and distributing military audio recordings of pilot-air traffic controller communication, the instructional designers were forced to use what is termed "civil," as opposed to "military," audio recordings for the listening activities. These civil aeronautical English recordings contain much vocabulary that is similar to civil aviation phraseology, but many phrases are unique to military aviation language. Also, because civil and military aircraft differ, the audio communication incorporated into the listening activities dealt only with civil aircraft parts. The use of civil aviation phraseology alone restricts the extent to which the instructional designers could expand the target audience's phraseology, and the content to include in the lessons. It would be ideal for the improved "Aeronautical English 101 for Controllers" unit to incorporate more authentic tasks related primarily to military aviation language and innovative technology (PARK, 2018), referencing the indigenous assessment criteria in the military context (PARK, 2020); this will help ensure the instruction expands learners' ATC phraseology in the exact contexts in which they will be used.

\section{References}

AGLUGUB, C. E. 2013. The relationship between learning style and job performance of U.S. Navy aviation maintenance technicians. Doctoral dissertation, Embry-Riddle Aeronautical University. ALDERSON, C. 2009. Air Safety, Language Assessment Policy, and Policy Implementation: The Case of Aviation English. Annual Review of Applied Linguistics, 29: 168-187.

ALDERSON, J. C.; M. SCOTT. 1992. Insiders, outsiders and participatory evaluation. In ALDERSON, J. C.; A. BERETTA (Eds). Evaluating second language education. Cambridge, UK: Cambridge University Press, p. 25-58.

BACHMAN, L. F.; A. S. PALMER. 1996. Language testing in practice: Designing and developing useful language tests. Oxford: Oxford University Press.

BERLYNE, D. 1965. Structure and Direction in Thinking. New York: John Wiley and Sons, Inc. BOSCHEN, A.C.; R.K.JONES. 2004. Aviation language problem: Improving pilot-controller communication. Paper presented at the Professional Communication Conference, IPCC 2004, 29 September-1 October, p. 291-299.

BROWN, J. D. 1995. The elements of language curriculum: a systematic approach to program development. Boston: Heinle and Heinle.

CIVIL AVIATION AUTHORITY (CAA), 2006. European Safety plan 2006/07-2010/11. Safety Regulation Group, No.1, 2006.

CUSHING, S. 1994. Fatal words: communication clashes and aircraft crashes. Chicago, IL: University of Chicago Press. 
EUROCONTROL. 2006. The European action plan for the prevention of runway incursions. Available at: <http://www.eurocontrol.int/runwaysafety/gallery/content/ public/docs/EAPPRI\%201_2.pdf $>$. Access: 31 Aug 2008.

EUROCONTROL. 2017. European Action Plan for the Prevention of Runway Incursions (EAPPRI), Version 3.0. [online]. Available at: $<$ https://www.eurocontrol.int/sites/default/files/2019-06/europeanaction-plan-prevention-runway-incursions-v3.pdf>. Access: 22 Jun 2020.

ICAO. 2004. Manual on the Implementation of ICAO Language Proficiency Requirements (1st ed): International Civil Aviation Organization. International Civil Aviation Organization.

ICAO. 2009. Guidelines for Aviation English Training Programmes (Cir 323 AN/185). Montreal, Canada: International Civil Aviation Organization.

ICAO. 2016-a. Manual on Air Traffic Controller Competency-based Training and Assessment (Doc 10056 AN/519). Montreal, Canada: International Civil Aviation Organization.

ICA0. 2016-b. Procedures for air navigation services-air traffic management (Doc 4444).

Montreal, Canada: International Civil Aviation Organization.

KARIMI, P.; R.V. SANAVI. 2014. Analyzing English language learning needs among students in aviation training program. Procedia-Social and Behavioral Sciences, 98, 852-858.

KELLER, J. 1987. Strategies for stimulating the motivation to learn. Performance \& Instruction, 26.8: $1-7$.

KRUSE, K. 2011. Introduction to instructional design and the ADDIE model. Available at:

$<$ http://www.transformativedesigns.com/id systems.html>. Access: 30 Jun 2020.

MEISHELLA, T. H. 2018. Designing English speaking material for cabin crew in Jogja Flight School. Doctoral dissertation, Sanata Dharma University.

MIDKIFF, A. H.; R.J. HANSMAN; T.G. REYNOLDS. 2004. Air carrier flight operations. Cambridge, MA: MIT International Center for Air Transportation.

MOERE, A.V.; M. SUZUKI; R. DOWNEY; J. CHENG. 2009. Implementing ICAO Language

Proficiency Requirements in the Versant Aviation English Test. Australian Review of Applied

Linguistics, 32.3: 27.1-27.17.

MOLENDA, M.; C.M. REIGELUTH; L.M. NELSON. 2003. Instructional design. In L. Nadel (Ed.).

Encyclopedia of Cognitive Science, London, Nature Publishing Group, 2: 574-578.

MORRISON, G.R.; S.M. ROSS; J.E. KEMP. 2010. Designing Effective Instruction, 6th. ed. Hoboken, NJ: Wiley.

NETO, J. F. D. B. 2012. E-learning in Multi-cultural Environments: An Analysis of Online Cabin Crew Training. Dissertation, Embry-Riddle Aeronautical University. Available at:

$<$ https://commons.erau.edu/edt/28>. Access: 30 Aug 2020.

PARK, M. 2018. Innovative assessment of aviation English in a virtual world: Windows into cognitive and metacognitive strategies. ReCALL, 30:2: 196-213.

PARK, M. 2020. Investigating Target Tasks, Task Phases, and Indigenous Criteria for Military Aviation English Assessment. Language Assessment Quarterly, 17.3: 1-26.

PARRISH, P. 2009. Aesthetic principles for instructional design. Education Tech Research Dev, 57 :

511-528.

PRINZO, O.V. 1996. An analysis of approach control/pilot voice communications. No. DOT/FAA/AM96/26. Washington, DC: Federal Aviation Administration.

SEXTON AND COMPANY. 2012. Training Process. Denver, Colorado Training. Available at:

$<$ http://www.denvercoloradotraining.com/about-the-training-development-company/denver-coloradotraining-process/>. Access: 30 Aug 2020.

SHIN, D.; H. KIM. 2005. English for aviation specific purposes: needs analysis for English proficiency requirements. Korean Journal of Applied Linguistics, 21.2: 193-217. 
SILVA, A.L.B.C.; P. TOSQUI-LUCKS. 2020. Around the world in aeronautical and aviation English courses. Revista CBTecLE, 2:1. Available at:

$<$ https://revista.cbtecle.com.br/index.php/CBTecLE/article/view/274>. Access: 30 Aug 2020.

TIAN, X., S. SUPPASETSEREE. 2013. Development of an instructional model for online task-based interactive listening for EFL learners. English Language Teaching, 6.3: 30-41.

TIEWTRAKUL, T.; S.R. FLETCHER. 2010. The challenge of regional accents for aviation English language proficiency standards: A study of difficulties in understanding in air traffic control-pilot communications. Ergonomics, 53.2: 229-239.

WEVER, R.; G.V. ES; M. VERBEEK. 2006. Air-ground communication safety study: causes and recommendations. Brussels: EUROCONTROL.

Moonyoung Park is an Assistant Professor in the Department of Curriculum and Instruction in the Faculty of Education at the Chinese University of Hong Kong, Hong Kong SAR. He holds a PhD degree in Applied Linguistics and Technology and his research interests include aviation English assessment, language teacher education, and computer-assisted language learning. His current research is on AI chatbot development for aviation English training. He is the Vice President of the Asia-Pacific Association for Computer-Assisted Language Learning (APACALL: http://apacall.org/).

Sarah Huffman is the Assistant Director for the Center for Communication Excellence of the Graduate College at Iowa State University in Ames, Iowa, U.S.A. She holds a PhD degree in Applied Linguistics and Technology and her research interests include genre and discourse analysis, academic writing instruction, and writing tutor training. Her current research is on science communication instruction and online writing consultation. 


\section{APPENDIX}

\section{Part 1. Demographic}

\section{Needs Analysis Survey}

1. Your age:

2. Months as an air traffic controller:

3. Standardized English test score (e.g., TOEIC):

4. Have you studied or lived in a native English-speaking country?

5. If yes, which country?

6. Your education level: for how long?

Bachelor's degree in Master's degree in

7. Duration studying English language: years

Others in

\section{Part 2. Your Experience and Needs in Language Skills}

8. To what extent do you think the following skills are important in air traffic control? Importance

\begin{tabular}{cccc}
\hline Not important at all & Of average importance & Absolutely essential \\
1 & 2 & 3 & 5
\end{tabular}

Listening skills

Reading skills

Speaking skills

Writing skills

9. What specific language skills and abilities do you think air traffic controllers need across the four language skills (i.e., listening, reading, speaking, writing)?

10. To what extent have you experienced difficulties in the four language skills (speaking, listening, reading, and writing) when you perform air traffic control duties?

Difficulties

\begin{tabular}{ccccc}
\hline Very easy & & Neutral & & Very difficult \\
1 & 2 & 3 & 4 & 5
\end{tabular}

Your limited chances to practice English speaking

Your limited chances to practice English listening

Your limited chances to practice English reading

Your limited chances to practice English writing

11. What are the most important air traffic control tasks based on your experience? Please list at least five tasks. 
12. How would you best learn aviation English? Please rank the following from most preferred to least preferred. $(1=$ least preferred; $5=$ most preferred $)$

Face-To-Face Instruction ( )

Instructional Video ( )

Manual Book ( )

Audio file (MP3 player) ( )

Computer Simulation ( )

\section{Part 3. Listening}

13. How would you rate your English language listening proficiency?

$\begin{array}{lllll}1 & 2 & 3 & 4 & 5\end{array}$

Beginner Low Intermediate High Intermediate Advanced Expert

14. To what extent have you experienced aviation English listening difficulties in the following items?

Difficulties

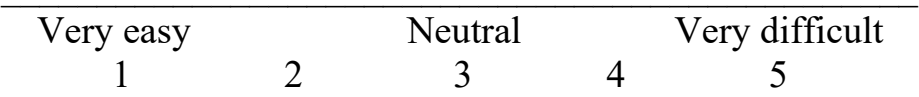

Korean pilot's English accents

Korean pilot's English speed of speech

Korean pilot's English pronunciation

Korean pilot's English grammar

Korean pilot's English comprehension problem

Korean pilot's non-standard aviation English phraseology

Korean pilot's use of specific terms you didn't learn

U.S. pilot's English accents

U.S. pilot's English speed of speech

U.S. pilot's English pronunciation

U.S. pilot's English grammar

U.S. pilot's English comprehension problem

U.S. pilot's non-standard aviation English phraseology

U.S. pilot's use of specific terms you haven't learned

15. Which language features are problematic for you when you are listening to native speaking pilots?

(mark all that apply)

- Pronunciation - Vocabulary - Grammar - Syntax (constructing sentences and entire thoughts)

16. Mark the levels of pronunciation it is difficult for you to understand when listening to a native speaking pilot:

- Words - Phrases - Sentences - Extended discourse

17. What ideas do you have for improving your listening skills?

\section{Part 4. Speaking}

18. How would you rate your English language speaking proficiency? 
1 Beginner
2

Low Intermediate
3

High Intermediate
4

Advanced
5

Expert

19. To what extent have you experienced difficulties in the following aviation English speaking tasks?

\section{Difficulties}

\begin{tabular}{ccccc}
\hline Very easy & & Neutral & & Very difficult \\
1 & 2 & 3 & 4 & 5
\end{tabular}

Conducting radio quality check

Providing terminal information

Approving take-off clearance

Approving frequency change

Providing weather service

Approving landing

Approving emergency landing

Others:

20. Which language features are problematic when you are speaking to native speaking pilots?

(mark all that apply)

- Pronunciation - Vocabulary - Grammar - Syntax (constructing sentences and entire thoughts)

- Others:

21. Of these, which is the most problematic when you speak in aviation English?

- Pronunciation - Vocabulary - Grammar - Syntax (constructing sentences and entire thoughts)

- Others:

22. Mark the levels of pronunciation where you have difficulties when speaking to a native English speaking pilot:

- Words - Phrases - Sentences - Extended discourse

23. What ideas do you have for improving your speaking skills?

24. What further suggestions or comments do you have for how your language skills could or should be improved so you are more successful at your job? 